\title{
ПСИХОЛОГИЧЕСКИЕ ОСОБЕННОСТИ СМЫСЛОВОЙ САМОРЕГУЛЯЦИИ БАНКОВСКИХ СЛУЖАЩИХ СРЕДНЕГО ЗВЕНА В ПЕРИОД ЭКОНОМИЧЕСКОГО КРИЗИСА
}

Кадякина Н.М.

Профессиональная деятельность сотрудников банков в условиях экономического кризиса обуславливает специфику смысложизненных стратегий личности и особенности ее смысловой саморегулячии. В прочессе профессиональной реализации банковских служащих среднего звена в зависимости от экономических и социальных условий происходит изменение мотивационной структуры и смысловых центраций в соответствии с имеющимися личностными ценностями, общей жизненной направленностью.

Ключевые слова: смысловая сфера личности, профессиональная самореал зация, смысложизненные стратегии, смысловая саморегуляция.

В последние два десятилетия в России происходит бурное развити банк ской сферы. Современная социальная ситуация развития нашего госу, ar o вă характеризуется радикальными изменениями, прежде всего, в поли иче көи и экономической сфере жизни общества. Интерес к деятельности банков в уповиях российской экономики значителен, о чем говорят исследования, ориенные, в первую очередь, к изучению банковского менеджемента (С.В. А. хиюова, С.В. Блохина, Т.В. Грицюк, Т.Н. Лобанова, В.Н. Молодожонова, Т.В. Никитина), формированию мотивационного механизма повышения эффективнос Муда работников банка (О.В. Васильева), развитию организационного консу ь - рования как фактора повышения эффективности деятельности банко-ки учреждений (Т.Н. Лобанова, Л.Г. Шац). Наиболее актуальными вопросами зл есь можно считать вопросы формирования кадровой политики банков (К? 1)шкарев) и изучения влияния психологических свойств личности на эф ект вность деятельности банковских служащих (И.В. Морозова) [3].

В то же время в психолого-акм ической литературе практически не встречаются работы, в которых радсма риватся проблемы оценки кризисных ситуаций в банковской системе тччи зрения влияния этой ситуации на ценностносмысловые особенности с (у) кащих, не изучены особенности личностных трансформаций именно ве Тус ции экономического кризиса. Однако исследования по психологии професиониьной деятельности, акмеологии, психологии управления и предпри 1иительства свидетельствуют, что особенности профессионального поведя ни, оудут зависеть от того, что является наиболее ценным для субъекта деятель кти, что имеет для него личностный смысл, иницирует смысложизненнь е ратегии, составляет «ядро» его смысложизненной концепции как системьн иболее устойчивых смысловых образований в интегральной саморегуяци личности [1, 2]. 
Ценностно-смысловое содержание профессиональной деятельности проявляется в саморегуляции, в качестве важнейшего показателя которой в данной работе мы рассматривали «меру уловлетворенности человека процессом своего труда» (Р.А. Зобов, В.Н. Келасьев), личностную устойчивость в различных профессиональных ситуациях.

Противоречие, возникшее в Российском обществе между реальным личностным потенциалом сотрудников банковской сферы и социально-психологическими тенденциями, связанными с последствиями экономического кризиса в стране и за рубежом, породило проблему исследования, состоящую в необходимости выявить, как общая переориентация банковской сферы сказывается на ценностно-смысловых ориентациях ее сотрудников, их профессиональных и жизненных перспективах, особенно работников среднего и низшего звена - банковских менеджеров.

Исследование проходило в несколько этапов:

-2007-2008 - органимзационно-диагностический;

-2008-2009 - коррекционный;

-2009 - завершающий.

Для достижения цели и решения задач исследования разработана спец альная методика исследования. В работе были использованы следующ иелітобды исследования: теоретический анализ литературы и документов Мо, енмрование, включенное наблюдение, тестирование, опросы, экспертные оцџки, изучение результатов деятельности.

В рамках психометрического подхода в процессе ис рдомания смысловой саморегуляции банковских служащих были выбраны следующие методики для исследования содержательно-смысловых компонен о смысловой саморегуляции: СЖО (Д.А. Леонтьев), «Методика предельных см. 'С 2з» (Д.А. Леонтьев), САМОАЛ (Н.Ф. Калина), «Ценностные ориентации» (М Р кич), «Направленность личности (Б. Басс), «Изучение самооценки с помощьюя бледуры ранжирования» (А.А.Реан). Для выявления мотивационно-динам ч $-g$ ких составляющих был использован ряд тестов: «Изучение мотивацион ых механизмов регуляции трудовой активности личности» (И.Г. Кокурино (1) титнгостика мотивационной структуры личности (В.Э. Мильман), диагнос ик Мотиваторов социально-психологической активности личности, экспресо Иатностика личностной конкурентноспособности (Н.П. Фетискин, В.В. Когео,Г.М. Мануйлов). Для компьютерной обработки данных использовались ста дартные статистические методы и программы: «Microsoft Excel 7.0» и «Statist 20 0 0 ».

В работе иси пьз вался опросник «Особенности смысловой саморегуляции работника б Н.ау (Шестаков А.А., 2001).

В резл ан анализа полученных диагностических данных, были получены следующи ыводы.

6. 'тановлено, что смысловая саморегуляция выступает как фактор, определяюш ий такие компоненты профессиональной успешности, как целеполагание, 0. еяна степени значимости условий профессиональной деятельности, построение 
программ собственных исполнительных действий, оценка соответствия реальных результатов критериям успеха, решения о необходимости и характере коррекций действий. Особенности смысловой саморегуляции личности включают в себя изменения содержательно-смысловых и динамически-мотивационных компонентов: смысложизненные и ценностные ориентации, самоактуализацию и самооценку; направленность личности, ее мотивационную структуру, социально-психологические мотиваторы личностной активности и ее конкурентноспособность.

В результате анализа диагностического материала были составлены характеристики мотивационно-динамических составляющих смысловой регуляции участников экспериментального исследования. Для банковских служащих характерна ярко выраженная мотивация преобразования и достижения. У женщин, которые составляли большинство респондентов, этот показатель сходен с эталонными характеристиками, свойственными для мужчин. Это касается, прежде всего, выраженной ориентации на достижения и сниженной ориентации на коммуникацию

2. Установлено, что смысловая саморегуляция обеспечивает индивидуальну 0 активность субъекта профессиональной деятельности, направленность насановление оптимальных отношений в профессиональной сфере, формирован состояния, способствующего профессиональной успешности: от жеско ддйктивной модели до возможности варьировать регуляторными обра зов нинии как стратегиями зависимого-независимого профессионального поведенм.При этом в зависимости от уровня развития смысловой саморегуляци борудники имеют разные профессиональные и смысложизненные стратеги

Так, успешные банковские служащие имеют следующую конфигурацию компонентов стратегии смысложизненной ориентации (4) ти > ЛК-Я > ЛК-Жизнь > Результат > Процесс. Успешные банковские служан'и уд удвлетворены своей жизнью в настоящем и средне оценивают пропук ввость пройденного отрезка жизни, при этом, однако, нацеленность в буду 4 -придает жизни полноценный смысл. Нацеленности на цели способствую ядсставления успешных банковских служащих о себе как о сильных личнос ах, бладающих достаточной свободой выбора, чтобы построить свою жизнь зоолетствии со своими целями и представлениями об её смысле, вопреки т му, - человеку не всегда дано контролировать свою жизнь, свободно принияа ғ решения и воплощать их в жизнь.

Банковские служащие сесо дним уровнем профессиональной реализации имеют следующую конфигура ию компонентов стратегии смысложизненной ориентации: Цели > Резуль $\mathrm{T}=$ ЛК-Я > ЛК-Жизнь > Процесс. Для них большое значение имеет наличие цеяи в жизи. Они не удовлетворены своей жизнью в настоящем. Они оцениваю- Сой жизненный путь в соответствии со своими представлениями о своих иинатных возможностях и свободе выбора, причем свобода выбора с точки зр ия этих работников в профессиональной реализации ограничена.

Со р) ники с низким уровнем профессиональной реализации более центрированы а себя, на решение своих проблем, по сравнению с высокой и средней оул. 1 ии профессиональной самореализации. При общей пассивности человека 
отсутствует связность компонентов саморегуляции, ее структурированность и интегрированность в смысловые образования. Если в первой группе представления о предельных основаниях человеческих действий образуют достаточно сложную связную структурную целостность, то для 3-й группы характерна предельная упрощенность этих представлений и их мозаичность - раздробленность на слабо связанные между собой составляющие с низким уровнем самореализации обнаруживают также понижение индекса децентрации по сравнению, как с респондентами среднего уровня самореализации, так и с испытуемыми, имеющими высокий уровень самореализации. Напротив, показатель негативности у них существенно повышается по сравнению с обеими этими группами (р меньше 0,01 в обоих случаях). Это характеризует представителей 3-й группы как людей, жизнь которых замкнута на самих себе, в круг привычных форм поведения, отклонение от которых вызывает дискомфорт. Индекс рефлексивности, как и следовало ожидать, во 2-й группе существенно выше, чем в 3-й. Мы расцениваем это как признак снижения в данои группе регулирующей роли сознания по отношению к профессиональной дея ель ности. Высокий показатель индекса децентрации характеризует испытуе иы. 1-ои и 2-ой групп как решительных, уверенных в своих силах, готовых осуниствля поставленные цели, реализовывать планы, отвечать не только за проф сс инаильную успешность и за успехи в собственной жизни, но и за жизнь и усп ехи, руиих людей.

3. Кадровая политика банка должна быть ориентирована מ́soбенности трансформации смысловой саморегуляции служащих срєдиер звена (менеджеров и экономистов) в период экономического кризиса к а. ва... ющего на социально-псиологический климат в коллективе.Составной частью работы служб по кадровому менеджменту и служб уг раления персоналом в банках должно стать психологическое сопровождение со् то пиков. Специальная коррекционная программа, разработанная в соотватс вии с особенностями смысловой саморегуляции банковских служащих, обеєг ние трудовой мотивации, адаптацию pa 9 ика в организации и его последующее профессиональное развитие; личн СТ, Ю устойчивость к критическим ситуациям; повышение эффективности гро фссиональной деятельности.

В условиях кризиса необхо ил широко практиковать систему моральных поощрений сотрудников, прумк ять ранговую систему продвижения по службе; использовать методы сам $ц$ ни сотрудниками своей работы параллельно оценкам, даваемым руковоғ итлями подразделений; постоянно практиковать горизонтальное перем ще ие работников, способствующее изучению смежных профессий; регуляюю пр водить семинары и тренинги для менеджеров и экономистов банков пстоянно информировать персонал о деятельности банка за определенны - ти оиоды, об открывшихся вакансиях и используемых элементах кадровой полими; использовать конкурсы при замещении различных должностей; тес а связь продвижения по службе с переподготовкой и повышением уровня знанц й, наличие в штатах банков кураторов - опытных менеджеров, которые осуц. - твляют наставничество над молодыми сотрудниками в течение нескольких лет. 


\section{Литература}

1. Абакумова И.В., Крутелева Л.Ю. Исследование компонентов интегральной смысловой саморегуляции личности в период профессионального становления. - Ростов-на-Дону: Изд-во Рост. гос. ун-та, 2004. - 61 с.

2. Деркач А.А. Реализация концепции Я в системе жизненных отношений личности (акмеологический аспект) // А.А. Деркач, Е.Б. Старовейтенко, А.Ю. Кривокулинский. - М.: РАУ, 1993. - 158 с.

3. Жуков Е.Ф. Менеджмент и маркетинг в банках:Учебное пособие для вузов. - М.: Банки и биржи, ЮНИТИ, 1997.

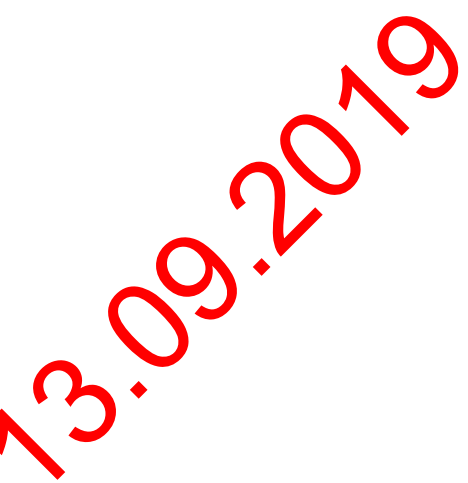

